First Peoples Child \& Family Review

A Journal on Innovation and Best Practices in Aboriginal Child Welfare Administration,

Research, Policy \& Practice

\title{
Foreword : Time Is Right To Reach Back And Look Forward
}

\section{Ivan Brown}

Volume 2, Number 1, 2005

URI: https://id.erudit.org/iderudit/1069533ar

DOI: https://doi.org/10.7202/1069533ar

See table of contents

Publisher(s)

First Nations Child and Family Caring Society of Canada

ISSN

1708-489X (print)

2293-6610 (digital)

Explore this journal

Cite this document

Brown, I. (2005). Foreword : Time Is Right To Reach Back And Look Forward. First Peoples Child \& Family Review, 2(1), 4-4. https://doi.org/10.7202/1069533ar viewed online.

https://apropos.erudit.org/en/users/policy-on-use/ 


\section{Time Is Right To Reach Back And Look Forward}

\section{Ivan Brown}

It is very encouraging indeed to see the collection of articles that appears between these covers, and that comprises the second issue of the First People's Child \& Family Review. This collection resulted from a request to a wide variety of authors to consider the topic Reconciliation in child welfare, and to generate some ideas that would contribute to our greater understanding of it.

The reason for this request was to help set the scene for a planned Reconciliation in Child Welfare Movement. This Movement is conceived as a North America wide dialog that will enable us to change our thinking and the nature of our relationships, and thus to move toward child welfare policy and practice that works to our better advantage.

One initial event will act as the "kickoff" for the Reconciliation Movement, but many other events - both large and small - are expected to follow. The initial event is entitled Reconciliation: Reaching Back, Looking Forward: Indigenous People and Child Welfare ${ }^{1}$ and will take place in Niagara Falls, Canada in October 2005. This will be an exciting opportunity for 200 invited leaders from across Canada and the United States to come together to help create the movement that will address - over the coming years - the best ways for Aboriginal and non-Aboriginal people to work together to support child welfare for Aboriginal children, families and communities.

To succeed, the Reconciliation Movement will have to be honest about historical and current relationships. In particular, it will have to recognize that it is essential to begin by looking at past harm and by understanding the reasons why that harm occurred. It will be just as important, however, to examine our current practices to see where imbalances of power and philosophy are still resulting in harm being perpetuated. Only by understanding - then altering - such imbalances in an open and willing way can Reconciliation truly begin to take place.

The articles in this issue of the First People's Child E Family Review help us along this path toward understanding. It will be our responsibility for knowing when we understand sufficiently to move forward and alter those things that are not in our children's best interests.

${ }^{1}$ Reconciliation: Reaching Back, Looking Forward: Indigenous People and Child Welfare is an event of the Centre of Excellence for Child Welfare, and is sponsored by the First Nations Child \& Family Caring Society of Canada, the National Indian Child Welfare Association (USA), the Child Welfare League of Canada, and the Child Welfare League of America.

\section{Ivan Brown, $\mathrm{Ph} . \mathrm{D}$.}

Ivan Brown is Manager of the Centre of Excellence for Child Welfare, a national Canadian centre for policy development and research. Dr. Brown is also an adjunct Associate Professor in the Faculty of Social Work, University of Toronto. He has published and spoken widely, particularly in his academic area of expertise; quality of life and disability. 